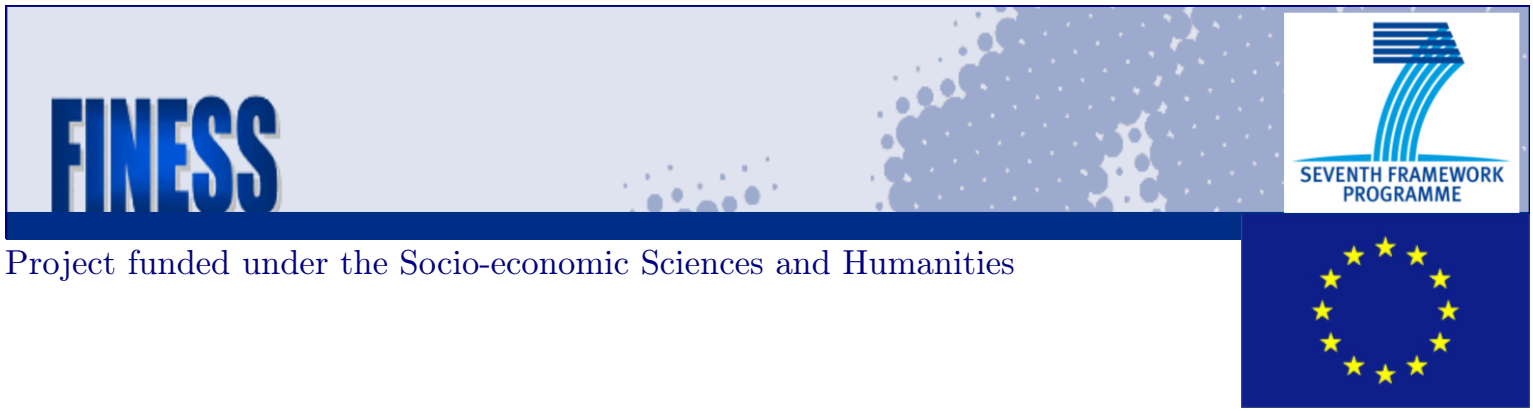

European Commission

Working Paper D.2.3

Bank-Specific Shocks and the Real Economy

Claudia M. Buch (University of Tübingen, IAW \& CESifo)

Katja Neugebauer (IAW \& University of Tübingen)

June 2010 


\title{
Bank-Specific Shocks and the Real Economy*
}

\author{
Claudia M. Buch (University of Tübingen, IAW \& CESifo) \\ Katja Neugebauer (IAW \& University of Tübingen) ${ }^{\dagger}$
}

\begin{abstract}
Government interventions into the financial system in the form of bail out operations or liquidity assistance are often justified with the systemic importance of large banks for the real economy. In this paper, we test whether idiosyncratic shocks to loan growth at large banks have effects on real GDP growth. We employ a measure of idiosyncratic shocks which follows Gabaix (2009). He shows that idiosyncratic shocks at large firms have an impact on GDP growth in the US. We apply this idea to the banking sector. We find evidence that changes in lending by large banks have a significant impact on GDP growth. This effect is mostly driven by episodes of negative loan growth rates and by the Eastern European countries in our sample.
\end{abstract}

Keywords: Granular Residual, idiosyncratic shocks, banking sector, size effects, GDP growth

JEL Classification: G21, E32

${ }^{*}$ Katja Neugebauer gratefully acknowledges financial support from the European Commission $\left(7^{\text {th }}\right.$ Framework Programme, Grant Agreement No. 217266). We thank Jörg Döpke, Jörn Kleinert, Kerstin Bernoth, and Sean Holly for most helpful discussions. All errors and inaccuracies are solely in our own responsibility.

${ }^{\dagger}$ Contact: Institute for Applied Economic Research, Ob dem Himmelreich 1, 72074 Tuebingen, Germany, Phone: +49 7071 989634, Fax: +49 7071 989699, e-mail: katja.neugebauer@iaw.edu 


\section{Motivation}

Government interventions into the financial system in the form of bail out operations or liquidity assistance are often justified with the systemic importance of large banks for the real economy. In this paper, we test whether idiosyncratic shocks to loan growth at large banks have effects on the real economy. We employ a measure of idiosyncratic shocks at large banks which follows Gabaix (2009). We apply this measure to the banking sectors in Europe, and we test whether shocks hitting the largest banks affect GDP growth. We find evidence that changes in lending by large banks have a significant impact on GDP growth. This effect is mostly driven by episodes of negative loan growth, and it is stronger for Eastern than for Western Europe.

The hypothesis that idiosyncratic shocks hitting individual firms (or banks) could have aggregate effects might seem surprising at first sight. If firm sizes were approximately normally distributed, idiosyncratic shocks should cancel out in the aggregate. Yet, Gabaix (2009) shows that idiosyncratic shocks (the "Granular Residual") that hit the largest 100 US firms can explain about 30 percent of fluctuations in per capita GDP growth. The reason for this lies in the unequal distribution of firm sizes. Firm size distributions are usually fat-tailed - there are only a few very large firms but a large number of small firms. Therefore, firm sizes follow a so-called power law distribution, and large idiosyncratic shocks might not cancel out in the aggregate.

Our application of this idea to the banking sector is motivated by two observations. First, financial and banking sector crises are often triggered by the failure or by increased instabilities of individual banks. The crisis that started in 2007 and that accelerated sharply after the fall of Lehman Brothers in September 2008, has forcefully shown this. We analyze the effects of shocks to the largest banks in an economy for a large cross-section of countries. The consequences of these shocks are measured in terms of their impact on the real economy. Second, government interventions into the financial system are typically justified with the systemic importance of individual financial institutions. Here, we test whether shocks at large banks indeed have an impact on the real economy.

We use a panel data set for 18 Western European and 17 Eastern European countries for the pre-crisis years 1996-2006 $(N=35, T=11)$. We construct the Granular Residual for the banking sector in each country separately, and we label this variable the Banking Granular Residual. We then test the impact of shocks at large banks on GDP growth. As in many recent theoretical models studying the interaction between banks and the real economy (Bernanke and Blinder 1988, Bernanke et al. 1996), the channel of transmission between the banking sector and the real economy is bank lending. Hence, we study episodes in which lending by large banks changes in response 
to idiosyncratic shock hitting these banks.

To the best of our knowledge, we are the first to apply the idea of the Granular Residual to an analysis of the real effects of financial shocks. ${ }^{1}$ In a related paper, Blank et al. (2009) look at the effects of shocks at large banks in Germany on the probability of distress at smaller banks and thus the transmission of shocks within the financial sector.

In addition, there are three strands of literature which are closely related to our analysis.

A first set of studies looks at the impact of banking and financial sector crises on real GDP growth. Dell'Ariccia et al. (2008) and Kroszner et al. (2007) find that industries with a high degree of financial dependence are hit most severely by financial shocks (See also Bonfiglioli and Mendicino (2005).). In Kroszner et al. (2007), financial crises are defined as periods during which the capital of the banking sector has been depleted due to loan losses, thus resulting in a negative net worth of the banking sector; Dell'Ariccia et al. (2008) study situations of systemic crises characterized by depositor runs, emergency measures taken by the government, high non-performing loans, or high fiscal costs of interventions in the banking system. Our proxy for shocks occurring at large banks differs from these measures because we not only focus on crises episodes, but we look at the link between GDP growth and shocks at large banks also during good times. While the shocks hitting large banks could become of systemic importance for the entire banking system, we not only focus on situations of systemic banking crises.

A second set of papers stresses the role of large banks for systemic risks in banking. Goel et al. (2009) find that idiosyncratic shocks suffered by a subset of banks can become systemic. Tarashev et al. (2009) find that the degree of systemic risk in the banking system is driven by banks' probability of default, the degree of size concentration of banks, and the banks' exposure to common (systematic) risk factors, either because of institutions' interconnectedness or because of similarity of their business models.

A third related strand of literature deals with the transmission of shocks within the financial system (Hasman and Samartín 2008, Allen and Gale 2007). Allen and Gale (2000) describe how interbank linkages can lead to contagion although a shock first occurs in only one bank. In their model, the probability of financial contagion depends on the linkages between individual banks (or regions) and the size of the initial shock.

The focus of our paper is on the impact of shocks at large banks on domestic growth. We essentially apply the idea of Allen and Gale (2000) to a situation in

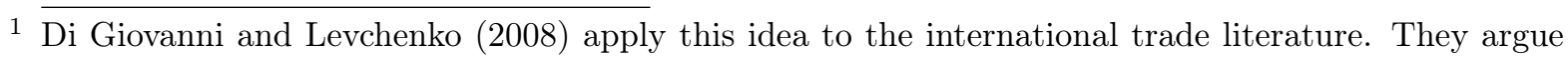
that opening up to trade increases the importance of large firms in an economy and this, in turn, could raise macroeconomic volatility. 
which a large bank in one country is hit by a shock, and we test whether this shock ultimately affects the real economy. We are agnostic about the exact nature of this contagion mechanism. One possible channel is that liquidity shocks and depositor runs force the banks to liquidate long-run projects, thus affecting the production capacity of the economy. An alternative mechanism would be that shocks hitting large banks affect confidence in the financial sector, thus leading to runs on other banks or negative effects on the interbank market, as seen in the crisis that began in 2007.

We combine these different strands of the literature. We look at the impact that shocks at large banks have on GDP growth. Our measure of shocks hitting banks is a continuous measure, hence we not only focus on crisis episodes. We largely avoid endogeneity problems because, by construction, our shock measure is idiosyncratic and thus exogenous. In the following Part 2, we describe the construction of the Banking Granular Residual, and we present stylized facts. Part 3 has the regression results, and Part 4 concludes.

\section{The Banking Granular Residual}

\subsection{Original Approach}

Originally, the idea of the Granular Residual has been developed to analyze the effects of idiosyncratic shocks at large firms on GDP growth (Gabaix 2009). To see the logic behind this, write the growth rate of firms' sales $S_{i, t}$ as

$$
g_{i, t+1}=\frac{\Delta S_{i, t+1}}{S_{i, t}}=\frac{S_{i, t+1}-S_{i, t}}{S_{i, t}}=\sigma_{i} \varepsilon_{i, t+1},
$$

where $\sigma_{i, t}$ denotes the volatility of firm $i$ 's sales, and $\varepsilon_{i, t+1}$ is an independent random shock variable with $\varepsilon_{i, t+1} \sim N(0,1)$. Aggregate GDP is given by

$$
Y_{t}=\sum_{i=1}^{N} S_{i, t}
$$

Assuming that firm-specific shocks are uncorrelated and that each firm has the same volatility, then the volatility of aggregate GDP can be written as

$$
\sigma_{G D P}=\sigma \sqrt{\sum_{i=1}^{N}\left(S_{i t} / Y_{t}\right)^{2}}=\sigma h
$$

where $h$ denotes the economy's Herfindahl-Hirschman Index. Equation (3) shows that the size distribution of firms determines the impact of idiosyncratic shocks on GDP 
volatility. If all firms were of equal size, each firm's impact on the volatility of GDP would be given by

$$
\sigma_{G D P}=\frac{\sigma}{\sqrt{N}} .
$$

For large $N$, the impact of idiosyncratic shocks on the volatility of GDP would become negligible. Gabaix $(2008,2009)$, however, shows that, under a Power Law distribution, idiosyncratic shocks do not cancel out. ${ }^{2}$

He constructs the so-called Granular Residual for the $K$ largest firms in the economy as

$$
G R_{t}=\left(\sum_{i=1}^{K} S_{i, t-1}\right)^{-1}\left(\sum_{i=1}^{K} S_{i, t-1}\left(g_{i t}-\overline{g_{t}}\right)\right)=\left(\sum_{i=1}^{K} S_{i, t-1}\right)^{-1}\left(\sum_{i=1}^{K} S_{i, t-1} \varepsilon_{i t}\right)
$$

where $\overline{g_{t}}=\frac{1}{K} \sum_{i=1}^{K} g_{i t}$, with $g_{i t}$ being a measure of productivity shocks at the individual firm, and $S_{i t}$ being the sales of the respective firm. Hence, the Granular Residual (GR) can be interpreted as the ratio between the size-weighted shocks of the largest $K$ firms in the economy relative to total sales. In an empirical application, Gabaix (2009) uses annual time series data for the years 1951-2001 for the largest US firms. He regresses US GDP growth on the Granular Residual, and he finds a statistically and economically significant effect.

\subsection{Application to Banking}

In our application to the banking industry, we modify the above set-up. Theoretical models studying the link between banks and the real economy assume that changes in bank lending affect investment or the availability of working capital and thus real output. Therefore, we do not resort to measures of bank productivity but proxy the Banking Granular Residual through changes in bank lending. Therefore, we calculate $g_{i t}$ according to

$$
g_{i t}=\ln (\text { total loans })_{t}-\ln (\text { total loans })_{t-1} .
$$

Furthermore, we calculate $\overline{g_{t}}$ according to $\overline{g_{t}}=\frac{1}{N} \sum_{i=1}^{N} g_{i t}$, where $N$ is the total number of banks in our sample. Hence, we subtract the mean over all banks in all economies, not only the $K$ largest ones in each country. This allows subtracting every systemic component and to take into account that different countries might be hit by the same (systemic) shock.

Furthermore, we have to take into account that the banking sectors in Europe differ in terms of the number of banks (minimum of 6 in the case of Estonia). Whereas, for

$2 \overline{\text { See Gabaix }(2008,2009) \text { for further details. }}$ 
instance, there are more than 1,500 German banks in our sample, this number is much smaller for many countries. Therefore, we cannot take a fixed number of the largest banks from each country as the market share of these banks would not be comparable across countries. Any alternative choice how to define the large banks is obviously arbitrary. We use all banks that each generate at least $5 \%$ of total operating income in the economy to get comparable results across countries. Since banking sector concentration in our sample is relatively moderate, we cannot set the threshold higher since this would result in too few banks per country used to calculate our shock measure. Therefore, the 5\%-threshold guarantees the inclusion of all the large and systemically important banks. Table 1 reports how many banks are used for the calculation of the Banking Granular Residual for each country.

Our source for the micro data needed to compute the Banking Granular Residual is Bankscope, provided by Bureau van Dijk. We retrieve data on all Western and Eastern European countries for the years 1996-2006. ${ }^{3}$ Some banks publish consolidated as well as unconsolidated statements. In order to avoid double entries, we use banks with the consolidation codes $\mathrm{C} 1$ (consolidated and companion is not on the disc), C2 (consolidated and companion is on the disc), U1 (unconsolidated and companion is not on the disc or if the bank does not publish consolidated accounts), and A1 (aggregated statements with no companion). We keep only commercial banks, savings banks, and cooperative banks. Furthermore, we eliminate all entries with missing operating income and set negative values for operating income equal to zero. In order to eliminate possible outliers, we set values for the Banking Granular Residual equal to -0.5 and +0.5 if they exceed this threshold.

Figures 1 and 2 display the Banking Granular Residual for Western and Eastern European countries. In terms of magnitudes, there are no large differences across countries. It is noticeable that the patterns for the Banking Granular Residual are quite distinct for each country. Most banking markets in Western Europe are very tranquil, but some have also witnessed relatively large shocks (such as Finland, Germany, Iceland, or Turkey). Generally, the dispersion of shocks is somewhat greater in Eastern Europe, and only a few markets there have shown a pattern as tranquil as some of the Western markets. Overall, there are not strong correlations in the patterns of the shocks across countries, thus reflecting the idiosyncratic nature of these shocks.

3 See Table 1 for an overview over the number of banks per country. 


\section{The Banking Granular Residual and Growth}

\subsection{Regression Specification}

Governments often justify interventions in the banking sector with the systemic effects of large banks which ultimately also reach the real economy. But how strong are these effects empirically? To answer this question, we regress growth in GDP per capita on our measure of (loan) shocks hitting large banks. Our baseline regression including up to $n$ lags looks as follows:

$$
\Delta G D P_{i, t}=\beta_{0}+\beta_{1} G R_{i, t}+\beta_{2} G R_{i, t-n}+\varepsilon_{i, t}
$$

We use panel data for a total of 35 Western and Eastern European countries and up to 11 years (1996-2006), i.e. our sample does not include the extreme events during the financial crisis that started in 2007. All equations are estimated using a panel fixedeffects estimator, as the Hausman test rejects the random effects estimator. Furthermore, we include a full set of time dummies to account for unobserved macroeconomic developments affecting all countries. Similar to Dell'Ariccia et al. (2008), our dependent variable is annual growth in GDP per capita. Previous literature has also used the average growth rate over a five year period (Bonfiglioli and Mendicino 2005) or a comparison of growth rates around periods of financial crises (Kroszner et al. 2007). While calculating growth rates over longer time windows would certainly be desirable, our sample is too short to implement such a model. However, we test whether our results are driven by including or excluding observations for individual years, and we find that results are robust.

\subsection{Baseline Regression Results}

Table 4 gives the results for our baseline regressions. Colums (1)-(2) report the results for the Banking Granular Residual that is calculated as described in section 2.2. The contemporaneous value of the Banking Granular Residual is positive and significant. Allowing for a sluggish response of GDP growth to changes in bank lending yields significant effects also for the first and second lag, and the overall effect is strongly significant and positive. Testing for the significance of the long-run coefficient, i.e. the sum of the short-run effects, also yields a highly significant result. In terms of explanatory power, the Banking Granular Residual, together with the time dummies, explains about $27 \%$ of the within variation in per capita GDP growth. The overall explanatory power is much smaller ( $\mathrm{R}^{2}$ of less than $4 \%$ ). Dropping the time dummies (unreported) gives values of $16 \%$ for the within- $\mathrm{R}^{2}$ and less than $1 \%$ of the overall- $\mathrm{R}^{2}$. Hence, our model performs quite well in terms of explaining cyclical variations in GDP 
growth within a given country, but it has low explanatory power in terms of explaining differences in growth across countries.

The methodology described so far is a relatively straightforward adoption of the original measure proposed by Gabaix (2009). We additionally account for the fact that bank-level growth might pick up (lagged) macroeconomic factors using a regressionbased approach by regressing the change in loan growth of bank $i$ on the mean change in this growth rate of all banks in country $i$, its own lag as well as aggregate GDP growth (both contemporaneous as well as lagged by one, two and three periods). Using the residual from this regression, we obtain a measure of idiosyncratic growth of bank $i$ which has been purged from all macroeconomic developments affecting the entire banking industry. As before, we then weight these shocks by size and sum over the largest banks. We re-run the baseline specification with our regression-based Banking Granular Residual as reported in column (3) of Table 4. The qualitative results remain by and large unchanged, but the first lag is now insignificant. Furthermore, the level of significance is somewhat reduced and the $R^{2}$ is lower. However, the long-run effect of the Banking Granular Residual is still significant.

\subsection{Robustness Tests}

The highly significant impact of the Banking Granular Residual might seem surprising at first sight, and it could be due to the fact that this variable picks up omitted variables, or it could be driven by a particular country or year. Therefore, we check the robustness of our results in a number of ways.

First, we split the full sample in Western and Eastern European sub-samples to take into account the different degree of development of financial markets in these regions. Results are presented in Table 5. A priori, we would expect a stronger impact of banking sector shocks on the real economy in Eastern than in Western Europe due to a lack of alternative financing possibilities. Our results in fact support this. The long-run effect of the Banking Granular Residual is positive and significant for both samples, and it is higher for the East (0.10 versus 0.06). Also, for Western Europe, results are weaker in the sense that the individual coefficients are insignificant. These results are not sensitive to specific country or year experiences. Dropping individual countries for the full sample or the Eastern European sub-samples leaves the main results unaffected.

Second, we estimate different coefficients for positive and negative shocks using interactions with an indicator variable. This acocunts for the fact that it might be difficult for firms to substitute away from bank loans to other forms of finance in the case of negative shocks to bank lending. Results are reported in Table 6. We find only a weak impact of positive shocks at large banks on the real economy. However, 
the estimates for negative shocks are positive and significant - if large banks contract lending, real GDP growth is lower as well. The long-run effect is significant as well, and it is driven by the episodes of negative loan growth. Again, the result remains intact if we drop individual countries one-by-one.

Third, we test whether standard growth-regression variables have the expected signs. We add these variables one-by-one because the sample size varies for the different variables. The upper half of Table 7 reports the results from augmenting our baseline specification with variables taken from standard growth regressions. We include lagged GDP growth (insignificant), ${ }^{4}$ school enrollment rates for secondary education (insignificant), the share of the labor force with secondary education (positive), population growth (negative), the government share of per capita GDP (negative), and the investment share (positive). These results are largely in line with expectations, and the Banking Granular Residual remains significant. Furthermore, the lower half of Table 7 reports the standardized beta coefficients of the respective regressions. These standardized coefficients allow us to judge the economic significance of the Banking Granular Residual. Compared with the standard growth regression variables, the economic significance of the Banking Granular Residual seems to be in a comparable range. This result underlines the importance that idiosyncratic shocks to loan supply have on per capita GDP growth.

Fourth, to account for the channels through which the Banking Granular Residual might affect the real economy, we include a number of variables capturing the structure of the domestic financial system (the ratio of private sector credit over GDP, capital controls, measures for the degree of concentration of the financial system). All are insignificant, as can be seen from Table 8, but the results for the Banking Granular Residual are qualitatively unchanged.

Finally, we check whether the Banking Granular Residual might be picking up the effects of crises episodes. In unreported regressions, we find that including different crisis dummies leaves the result for the Banking Granular Residual unaffected. We use a data set by Laeven and Valencia (2008) to control for different types of financial crises. The data set includes dummy variables that mark the onset of a banking crisis, a currency crisis, or a debt crisis. These dummies are uncorrelated with our regressionbased Banking Granular Residual, since they capture systemic crises events. We expect a negative sign on the crises dummies. However, when including the crises dummies one at a time, only the one indicating a debt crisis turns out to be significant. This is possibly due to the fact that only very few crises occurred during the period under consideration.

4 Including lagged GDP growth requires a dynamic panel estimate. We use the Arellano-Bond one-step GMM estimator with robust standard errors. Insignificance of the respective coefficient might be due to the fact that the Arellano-Bond-estimator is designed for large sample sizes. 


\section{Discussion and Conclusion}

Governments typically justify interventions in the financial system and in particular emergency measures targeted at large banks with the systemic effects that shocks hitting these banks could have. Idiosyncratic shocks affecting lending of the largest banks in an economy might even have negative implications for the real economy. In this paper, we propose a novel measure for shocks hitting large banks, the so-called Banking Granular Residual. We use a modified measure in the spirit of Gabaix (2009). Our Banking Granular Residual measures idiosyncratic shocks of loan growth at large banks which are purged from common factors affecting all banks. It is a measure of banking sector shocks which is continuously measured and exogenous. Using a panel data set for the years 1996-2006, we have analyzed the impact of the Banking Granular Residual on per capita GDP growth. Our study has three main findings.

First, idiosyncratic shocks to loan growth at large banks have a statistically and economically significant impact on real GDP growth. These shocks explain about $16 \%$ of the cyclical variation in per capita GDP growth within a given country but less than $1 \%$ of the total variance of GDP growth across countries. This result is robust with regard to adding standard growth regressors, structural features of the financial system, and dummies for crises episodes.

Second, negative and positive shocks to loan growth at large banks have different effects. Whereas the impact of positive shocks is hardly significant, the significant overall effect is driven by episodes of credit contractions. This is in line with theoretical models assuming that links between banks and the real economy are due to asymmetries in information and difficulties of borrowers to switch sources of finance. Difficulties of borrowers to switch from bank lending to alternative sources of finance in situations of distress would be consistent with our findings.

Third, Western and Eastern European countries differ. The positive link between loan growth and real GDP growth that we find is stronger for the Eastern European sub-sample than for Western Europe. The lower degree of development of banking markets in Eastern Europe and difficulties in switching to alternative providers of services, either at home or abroad, due to more severe asymmetries in information, would explain this finding.

In future work, it would be interesting to test the robustness of our findings and to apply a similar empirical strategy to the current crisis period. In addition, it would be interesting to quantify the possible costs and benefits of recent policy interventions. Our results suggest that, even though shocks hitting large banks may have a significant impact on the real economy, these shocks do not affect the long-run differences in growth rates across countries. Also, the real effects of these shocks are related to the state of 
development of the domestic financial system, showing the importance of implementing institutional reforms aimed at enhancing the resilience of the domestic banking system. 


\section{References}

Allen, F., \& Gale, D. (2000). Financial Contagion. Journal of Political Economy, 108(1), 1-33.

Allen, F., \& Gale, D. (2007). An Introduction to Financial Crises. In M. Blaug (Ed.), Financial Crises. The International Library of Critical Writing in Economics. Edward Elgar.

Beck, T., Demirgüç-Kunt, A., \& Levine, R. (2000). A New Database on Financial Development and Structure. World Bank Economic Review, 14, 597-605.

Bernanke, B., Gertler, M., \& Gilchrist, S. (1996). The Financial Accelerator and the Flight to Quality. The Review of Economics and Statistics, 78(1), 1-15.

Bernanke, B. S., \& Blinder, A. S. (1988). Credit, Money, and Aggregate Demand. American Economic Review, 78(2), 435-39.

Blank, S., Buch, C. M., \& Neugebauer, K. (2009). Shocks at Large Banks and Banking Sector Distress: The Banking Granular Residual. Journal of Financial Stability, 5(4), 353-373.

Bonfiglioli, A., \& Mendicino, C. (2005). Financial Liberalization, Bank Crises and Growth: Assessing the Links (Departmental Working Papers of Economics - University 'Roma Tre' No. 0044). Department of Economics - University Roma Tre, Rome.

Dell'Ariccia, G., Detragiache, E., \& Rajan, R. (2008). The Real Effect of Banking Crises. Journal of Financial Intermediation, 17(1), 89-112.

Gabaix, X. (2008). Power Laws in Economics and Finance. NBER Working Paper No.14299.

Gabaix, X. (2009). The Granular Origins of Aggregate Fluctuations. NBER Working Paper No.15286.

Goel, A. M., Song, F., \& Thakor, A. V. (2009). Infectious Leverage [Working Paper Series]. SSRN eLibrary.

Hasman, A., \& Samartín, M. (2008). Information Acquisition and Financial Contagion. Journal of Banking \& Finance, 32(10), 2136 - 2147.

Kroszner, R. S., Laeven, L., \& Klingebiel, D. (2007). Banking Crises, Financial Dependence, and Growth. Journal of Financial Economics, 84(1), 187 - 228.

Laeven, L., \& Valencia, F. (2008). Systemic Banking Crises: A New Database (IMF Working Papers No. 08/224). International Monetary Fund.

Schindler, M. (2009). Measuring Financial Integration: A New Data Set. IMF Staff Papers, 56(1), 222-238.

Tarashev, N., Borio, C., \& Tsatsaronis, K. (2009). The Systemic Importance of Financial Institutions. BIS Quarterly Review, September. 


\section{A Tables and Figures}

\section{Table 1: Number of Banks by Country}

Table 1 gives an overview over the number of banks in our sample by country. The table is split into Western and Eastern Europe. Percentages are given with respect to the sum of banks in both sub-samples. The penultimate column gives the number of banks that are used to calculate the Banking Granular Residual. The last column reports the banking sectors' Herfindahl-Hirschman Index, calculated by using operating income.

\begin{tabular}{|c|c|c|c|c|}
\hline Country name & No. of banks & $\%$ of total & Number of banks for GR & Banking Sector Herfindahl \\
\hline \multicolumn{5}{|l|}{ Western Europe } \\
\hline AUSTRIA & 240 & 4.46 & 6 & 0.149 \\
\hline BELGIUM & 58 & 1.08 & 5 & 0.247 \\
\hline DENMARK & 96 & 1.79 & 4 & 0.221 \\
\hline FINLAND & 10 & 0.19 & 6 & 0.451 \\
\hline FRANCE & 294 & 5.47 & 8 & 0.052 \\
\hline GERMANY & 1654 & 30.77 & 4 & 0.072 \\
\hline GREECE & 18 & 0.33 & 6 & 0.185 \\
\hline ICELAND & 27 & 0.50 & 4 & 0.341 \\
\hline IRELAND & 35 & 0.65 & 5 & 0.278 \\
\hline ITALY & 674 & 12.54 & 10 & 0.109 \\
\hline NETHERLANDS & 46 & 0.86 & 4 & 0.273 \\
\hline NORWAY & 64 & 1.19 & 7 & 0.191 \\
\hline PORTUGAL & 24 & 0.45 & 5 & 0.267 \\
\hline SPAIN & 144 & 2.68 & 6 & 0.141 \\
\hline SWEDEN & 92 & 1.71 & 3 & 0.288 \\
\hline SWITZERLAND & 409 & 7.61 & 7 & 0.593 \\
\hline TURKEY & 32 & 0.60 & 8 & 0.314 \\
\hline UNITED KINGDOM & 145 & 2.70 & 8 & 0.119 \\
\hline \multicolumn{5}{|l|}{ Eastern Europe } \\
\hline BELARUS & 17 & 0.32 & 7 & 0.389 \\
\hline BOSNIA-HERZEGOVINA & 22 & 0.41 & 12 & 0.125 \\
\hline BULGARIA & 25 & 0.47 & 8 & 0.153 \\
\hline CROATIA & 35 & 0.65 & 8 & 0.190 \\
\hline CZECH REPUBLIC & 21 & 0.39 & 4 & 0.238 \\
\hline ESTONIA & 6 & 0.11 & 3 & 0.594 \\
\hline HUNGARY & 27 & 0.50 & 12 & 0.195 \\
\hline LATVIA & 22 & 0.41 & 12 & 0.271 \\
\hline LITHUANIA & 10 & 0.19 & 5 & 0.323 \\
\hline MACEDONIA (FYROM) & 13 & 0.24 & 5 & 0.330 \\
\hline MOLDOVA REP. OF & 16 & 0.30 & 9 & 0.313 \\
\hline POLAND & 46 & 0.86 & 17 & 0.137 \\
\hline ROMANIA & 25 & 0.47 & 9 & 0.198 \\
\hline RUSSIAN FEDERATION & 937 & 17.43 & 15 & 0.205 \\
\hline SLOVAKIA & 14 & 0.26 & 9 & 0.240 \\
\hline SLOVENIA & 19 & 0.35 & 9 & 0.413 \\
\hline UKRAINE & 59 & 1.10 & 18 & 0.137 \\
\hline Total & 5376 & 100 & 268 & \\
\hline
\end{tabular}


Table 2: Variables: Definition and Sources

\begin{tabular}{|l|l|l|}
\hline \hline Variable & Definition & Sources \\
\hline \hline Granular Residual & $\begin{array}{l}\text { Size-weighted idiosyncratic shocks as defined in } \\
\text { section 2.1 }\end{array}$ & $\begin{array}{l}\text { own calculations from } \\
\text { Bankscope }\end{array}$ \\
\hline $\begin{array}{l}\text { Reg. Granular Resid- } \\
\text { ual }\end{array}$ & $\begin{array}{l}\text { Regression-based Banking Granular Residual } \\
\text { as defined in section 2.1 }\end{array}$ & $\begin{array}{l}\text { own calculations from } \\
\text { Bankscope }\end{array}$ \\
\hline$\Delta$ GDP & Annual growth of real per capita GDP & $\begin{array}{l}\text { World Development In- } \\
\text { dicators (WDI) }\end{array}$ \\
\hline Private sector credit & Bank deposits / GDP & Beck et al. (2000) \\
\hline Capital controls & Overall restrictions index on all asset classes & Schindler (2009) \\
\hline Government share & Government share of real per capita GDP & Penn World Tables \\
\hline Investment share & Investment share of real per capita GDP & Penn World Tables \\
\hline Herfindahl & Herfindahl-Hirschman Index & $\begin{array}{l}\text { Own calculations from } \\
\text { Bankscope }\end{array}$ \\
\hline $\begin{array}{l}\text { School enrollment sec- } \\
\text { ondary }\end{array}$ & $\begin{array}{l}\text { School enrollment rates for secondary educa- } \\
\text { tion }\end{array}$ & $\begin{array}{l}\text { World Development In- } \\
\text { dicators (WDI) }\end{array}$ \\
\hline $\begin{array}{l}\text { Labor force with sec- } \\
\text { ondary edu }\end{array}$ & $\begin{array}{l}\text { Share of the labor force with secondary educa- } \\
\text { tion }\end{array}$ & $\begin{array}{l}\text { World Development In- } \\
\text { dicators (WDI) }\end{array}$ \\
\hline Population growth & Average yearly population growth rate & Penn World Tables \\
\hline \hline
\end{tabular}

Table 3: Descriptive Statistics

\begin{tabular}{lccccc}
\hline \hline Variable & $\begin{array}{c}\text { Number } \\
\text { of Obser- } \\
\text { vations }\end{array}$ & Mean & $\begin{array}{c}\text { Standard } \\
\text { Devia- } \\
\text { tion }\end{array}$ & Minimum & Maximum \\
\hline Granular Residual & 331 & -0.0094 & 0.1648 & -0.5000 & 0.5000 \\
Reg. Granular Residual & 331 & -0.0021 & 0.1440 & -0.5000 & 0.5000 \\
$\Delta$ GDP & 331 & 0.0375 & 0.0305 & -0.0634 & 0.1295 \\
Private sector credit & 297 & 0.5499 & 0.2968 & 0.0839 & 1.6018 \\
Capital controls & 211 & 0.1552 & 0.2656 & 0.0000 & 1.0000 \\
Government share & 171 & 0.2168 & 0.0613 & 0.1233 & 0.3713 \\
Investment share & 171 & 0.2159 & 0.0344 & 0.0949 & 0.3037 \\
Herfindahl & 331 & 0.2482 & 0.1550 & 0.0464 & 0.9804 \\
School enrollment secondary & 176 & 0.8819 & 0.0592 & 0.6603 & 0.9926 \\
Labor force with secondary edu & 216 & 0.4908 & 0.1709 & 0.1080 & 0.8050 \\
Population growth & 172 & 0.0019 & 0.0047 & -0.0102 & 0.0188 \\
\hline \hline
\end{tabular}


Figure 1: Granular Residuals for Western Europe

Figure 1 shows the evolution of the Banking Granular Residual for countries in Western Europe over time.
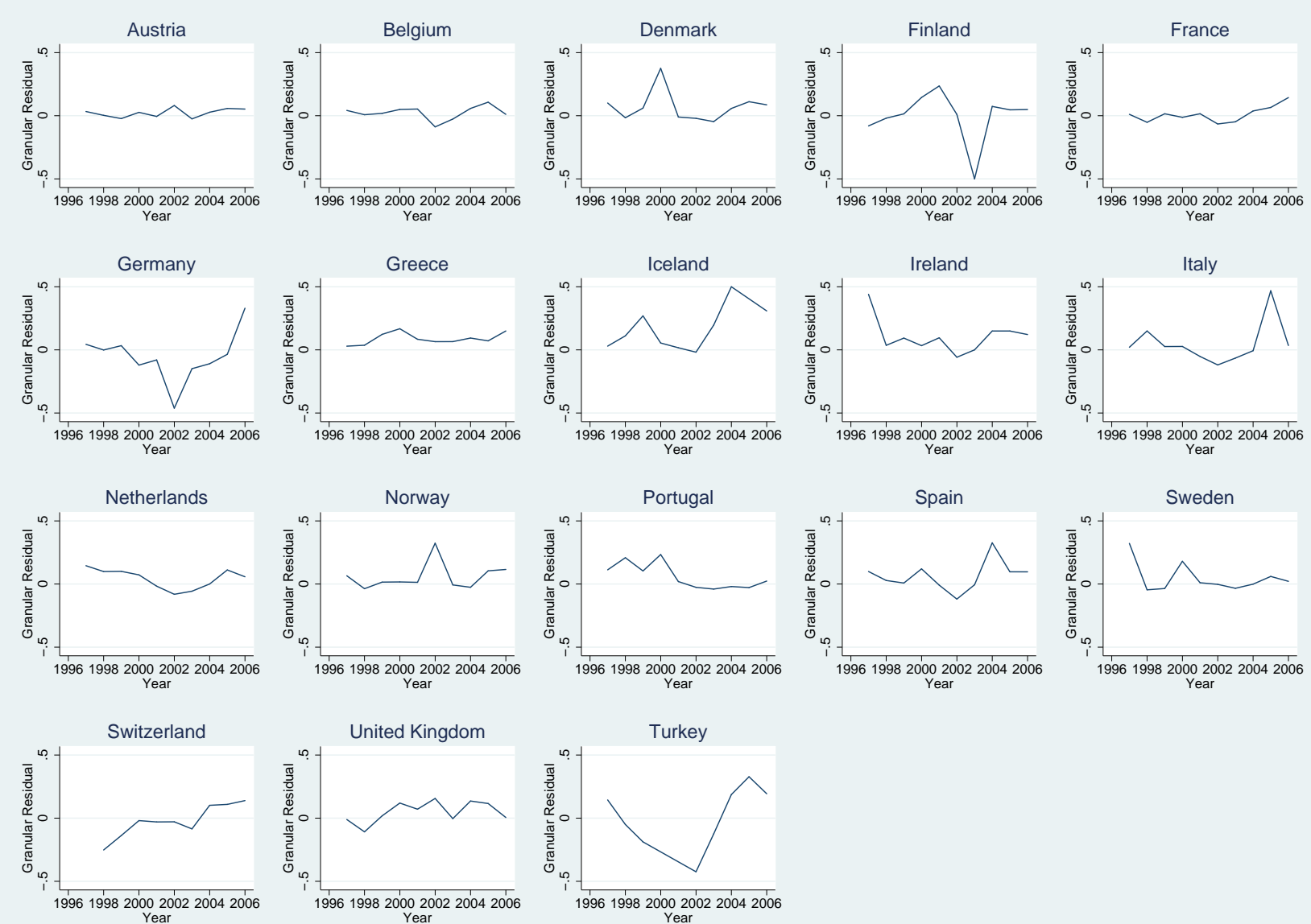
Figure 2: Granular Residuals for Eastern Europe

Figure 2 shows the evolution of the Banking Granular Residual for countries in Eastern Europe over time.
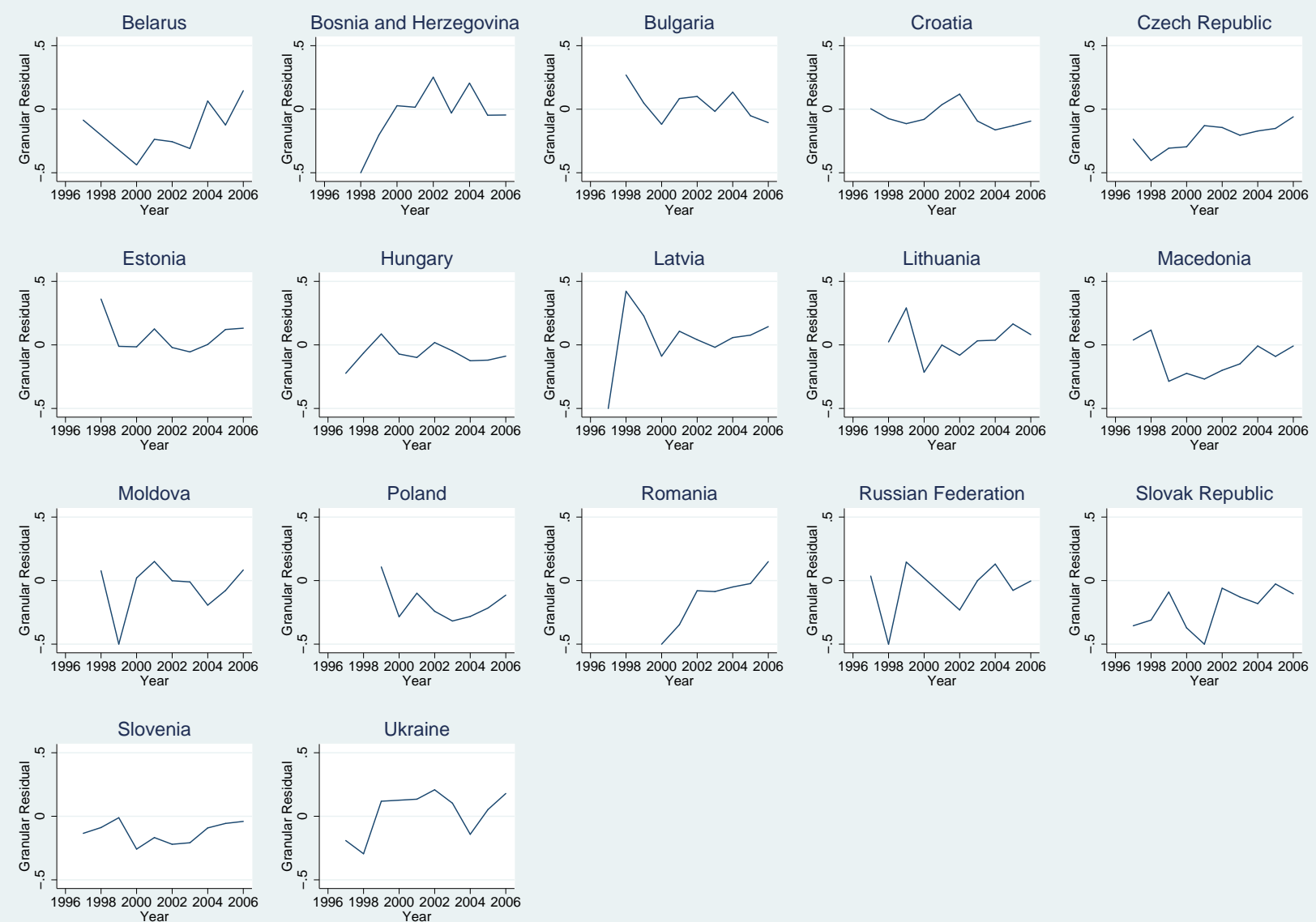
Table 4: Baseline Regressions

This table reports the results for the panel fixed-effects estimation of the Baseline Regression. Granular Residual(-1) and Granular Residual(-2) indicate the inclusion of the respective lags of the Banking Granular Residual. Reg. Granular Residual is the regression-based version of the Banking Granular Residual. The dependent variable is per capita GDP growth. All regressions include a set of time dummies. ${ }^{* *},{ }^{* *}$, and ${ }^{*}$ denote significance at the $1 \%$-, $5 \%$-, and $10 \%$-level, respectively.

\begin{tabular}{llll}
\hline \hline & $(1)$ & $(2)$ & $(3)$ \\
\hline Granular Residual & $0.0315^{* *}$ & $0.0446^{* * *}$ & \\
& $(0.0154)$ & $(0.0141)$ & \\
Granular Residual(-1) & & $0.0273^{*}$ \\
$(0.0152)$ & \\
Granular Residual(-2) & & $0.0244^{* *}$ & \\
& & $(0.0109)$ & $0.0233^{*}$ \\
Reg. Granular Residual & & $(0.0122)$ \\
Reg. Granular Residual(-1) & & 0.0146 \\
& & & $(0.0147)$ \\
Reg. Granular Residual(-2) & & & $0.0233^{* *}$ \\
& & & $(0.0114)$ \\
Long-Run Effect & & $0.0963^{* * *}$ & $0.0612^{* *}$ \\
& & $(0.0209)$ & $(0.0232)$ \\
Observations & 331 & 253 & 253 \\
Number of Countries & 35 & 35 & 35 \\
R-Squared & 0.125 & 0.273 & 0.199 \\
\hline \hline
\end{tabular}


Table 5: Sample Split: Western Europe vs. Eastern Europe

This table reports the regression results for the panel fixed-effects estimation with sample splits between Western and Eastern Europe. The dependent variable is per capita GDP growth. All regressions include a set of time dummies. ${ }^{* * *},{ }^{* *}$, and ${ }^{*}$ denote significance at the $1 \%-, 5 \%$, and $10 \%$-level, respectively.

\begin{tabular}{|c|c|c|c|}
\hline & Full Sample & Western Europe & Eastern Europe \\
\hline \multirow{2}{*}{ Granular Residual } & $0.0446^{* * *}$ & 0.0376 & $0.0438^{* *}$ \\
\hline & $(0.0141)$ & $(0.0244)$ & $(0.0158)$ \\
\hline \multirow[t]{2}{*}{ Granular Residual(-1) } & $0.0273^{*}$ & 0.0149 & 0.0278 \\
\hline & $(0.0152)$ & $(0.0089)$ & $(0.0226)$ \\
\hline \multirow[t]{2}{*}{ Granular Residual(-2) } & $0.0244^{* *}$ & 0.00828 & $0.0273^{*}$ \\
\hline & $(0.0109)$ & $(0.0198)$ & $(0.0133)$ \\
\hline \multirow[t]{2}{*}{ Long-Run Effect } & $0.0963^{* * *}$ & $0.0608^{* *}$ & $0.0990^{* * *}$ \\
\hline & $(0.0209)$ & $(0.0230)$ & $(0.0306)$ \\
\hline Observations & 253 & 137 & 116 \\
\hline Number of Countries & 35 & 18 & 17 \\
\hline R-Squared & 0.273 & 0.384 & 0.388 \\
\hline
\end{tabular}


Table 6: Sample Split: Positive Residuals vs. Negative Residuals

This Table reports the regression results for the panel fixed-effects estimation with sample splits between positive and negative residuals. The dependent variable is per capita GDP growth. All regressions include a set of time dummies. ${ }^{* * *},{ }^{* *}$, and ${ }^{*}$ denote significance at the $1 \%^{-}, 5 \%$, and $10 \%$-level, respectively.

\begin{tabular}{|c|c|c|c|c|}
\hline & $(1)$ & $(2)$ & $(3)$ & $(4)$ \\
\hline Granular Residual & $\begin{array}{l}0.0446^{* * *} \\
(0.0141)\end{array}$ & & & \\
\hline Granular Residual(-1) & $\begin{array}{l}0.0273^{*} \\
(0.0152)\end{array}$ & & & \\
\hline Granular Residual(-2) & $\begin{array}{l}0.0244^{* *} \\
(0.0109)\end{array}$ & & & \\
\hline Positive Granular Residual & & $\begin{array}{l}0.0400^{*} \\
(0.0218)\end{array}$ & & $\begin{array}{l}0.0268 \\
(0.0202)\end{array}$ \\
\hline Positive Granular Residual(-1) & & $\begin{array}{l}0.0199 \\
(0.0257)\end{array}$ & & $\begin{array}{l}0.00956 \\
(0.0211)\end{array}$ \\
\hline Positive Granular Residual(-2) & & $\begin{array}{l}0.0328^{*} \\
(0.0190)\end{array}$ & & $\begin{array}{l}0.0280 \\
(0.0186)\end{array}$ \\
\hline Negative Granular Residual & & & $\begin{array}{l}0.0677^{* * *} \\
(0.0204)\end{array}$ & $\begin{array}{l}0.0649 * * * \\
(0.0183)\end{array}$ \\
\hline Long-Run Effect & $\begin{array}{l}0.0963^{* * *} \\
(0.0209)\end{array}$ & $\begin{array}{l}0.0927^{*} \\
(0.0498)\end{array}$ & $\begin{array}{l}0.1386^{* * *} \\
(0.0262)\end{array}$ & $\begin{array}{l}0.1923^{* * *} \\
(0.0476)\end{array}$ \\
\hline Observations & 253 & 253 & 253 & 253 \\
\hline Number of Countries & 35 & 35 & 35 & 35 \\
\hline R-Squared & 0.273 & 0.196 & 0.269 & 0.289 \\
\hline
\end{tabular}




\section{Table 7: Standard Growth-Regression Variables}

The upper half of this table reports the regression results for the baseline regression and its augmentations by different variables that are included in standard growth regressions. Column (2) adds lagged per capita GDP growth. Column (3) adds the school enrollment rate for secondary education to the baseline specification. Column (4) adds the percentage of labor force with secondary education. Column (5) adds average population growth. Columns (6) and (7) add the government and investment share of per capita GDP, respectively. The dependent variable is per capita GDP growth. The regression specification in column (2) is estimated with an Arellano-Bond estimator. All other regressions specifications are estimated with panel fixed effects. All regressions include a set of time dummies. ${ }^{* *},{ }^{* *}$, and ${ }^{*}$ denote significance at the $1 \%-, 5 \%$-, and $10 \%$-level, respectively. The lower half of this table reports the standardized beta coefficients for the respective regressions.

\begin{tabular}{|c|c|c|c|c|c|c|c|}
\hline & $(1)$ & $(2)$ & $\overline{(3)}$ & $(4)$ & $(5)$ & $(6)$ & $(7)$ \\
\hline Granular Residual & $\begin{array}{l}0.0446^{* * *} \\
(0.0141)\end{array}$ & $\begin{array}{l}0.0339 * * * \\
(0.0112)\end{array}$ & $\begin{array}{l}0.0354^{* *} \\
(0.0166)\end{array}$ & $\begin{array}{l}0.0483^{* *} \\
(0.0234)\end{array}$ & $\begin{array}{l}0.0352^{* * *} \\
(0.0124)\end{array}$ & $\begin{array}{l}0.0308 * * * \\
(0.0102)\end{array}$ & $\begin{array}{l}0.0204 \\
(0.0130)\end{array}$ \\
\hline Granular Residual(-1) & $\begin{array}{l}0.0273^{*} \\
(0.0152)\end{array}$ & $\begin{array}{l}0.0213 \\
(0.0145)\end{array}$ & $\begin{array}{l}0.0368^{*} \\
(0.0196)\end{array}$ & $\begin{array}{l}-0.0020 \\
(0.0097)\end{array}$ & $\begin{array}{l}-0.0014 \\
(0.0113)\end{array}$ & $\begin{array}{l}0.0048 \\
(0.0091)\end{array}$ & $\begin{array}{l}-0.0021 \\
(0.0092)\end{array}$ \\
\hline Granular Residual(-2) & $\begin{array}{l}0.0244^{* *} \\
(0.0109)\end{array}$ & $\begin{array}{l}0.0182^{* *} \\
(0.0084)\end{array}$ & $\begin{array}{l}0.0239^{*} \\
(0.0120)\end{array}$ & $\begin{array}{l}0.0055 \\
(0.0177)\end{array}$ & $\begin{array}{l}0.0272^{* * *} \\
(0.0078)\end{array}$ & $\begin{array}{l}0.0273^{* * *} \\
(0.0090)\end{array}$ & $\begin{array}{l}0.0259^{* *} \\
(0.0092)\end{array}$ \\
\hline$\Delta \mathrm{GDP}(-1)$ & & $\begin{array}{l}-0.0671 \\
(0.0986)\end{array}$ & & & & & \\
\hline School enrollment secondary & & & $\begin{array}{l}0.1330 \\
(0.1050)\end{array}$ & & & & \\
\hline $\begin{array}{l}\text { Labor force with secondary } \\
\text { edu }\end{array}$ & & & & $\begin{array}{l}0.0907^{* * *} \\
(0.0206)\end{array}$ & & & \\
\hline Population growth & & & & & $\begin{array}{l}-4.1050^{* *} \\
(1.5420)\end{array}$ & & \\
\hline Government share & & & & & & $\begin{array}{l}-0.7230 * * * \\
(0.1470)\end{array}$ & \\
\hline Investment share & & & & & & & $\begin{array}{l}0.3780^{* * *} \\
(0.1220)\end{array}$ \\
\hline Long-Run Effect & $\begin{array}{l}0.0963^{* * *} \\
(0.0209)\end{array}$ & $\begin{array}{l}0.0733^{* * *} \\
(0.0258) \\
\end{array}$ & $\begin{array}{l}0.0962^{* * *} \\
(0.0307)\end{array}$ & $\begin{array}{l}0.0518^{* *} \\
(0.0244)\end{array}$ & $\begin{array}{l}0.0610^{* * *} \\
(0.0189)\end{array}$ & $\begin{array}{l}0.0629 * * * \\
(0.0197)\end{array}$ & $\begin{array}{l}0.0442^{*} \\
(0.0232)\end{array}$ \\
\hline Observations & 253 & 215 & 160 & 161 & 128 & 127 & 127 \\
\hline Number of Countries & 35 & 35 & 28 & 31 & 22 & 22 & 22 \\
\hline R-Squared & 0.273 & n.a. & 0.328 & 0.318 & 0.437 & 0.480 & 0.447 \\
\hline & & & & ardized Coe & ients & & \\
\hline Granular Residual & 0.2411 & 0.1833 & 0.1914 & 0.2611 & 0.1903 & 0.1665 & 0.1103 \\
\hline Granular Residual(-1) & 0.1476 & 0.1152 & 0.1989 & -0.0108 & -0.0076 & 0.0259 & -0.0114 \\
\hline Granular Residual(-2) & 0.1319 & 0.0984 & 0.1292 & 0.0297 & 0.1470 & 0.1476 & 0.1400 \\
\hline$\Delta \mathrm{GDP}(-1)$ & & -0.0671 & & & & & \\
\hline School enrollment secondary & & & 0.2582 & & & & \\
\hline $\begin{array}{l}\text { Labor force with secondary } \\
\text { edu }\end{array}$ & & & & 0.5086 & & & \\
\hline Population growth & & & & & -0.6342 & & \\
\hline Government share & & & & & & -1.4533 & \\
\hline Investment share & & & & & & & 0.4269 \\
\hline
\end{tabular}


Table 8: Financial System Indicators

This table reports the regression results for the baseline regression and its augmentations by different variables that proxy for the structure of the financial system. Column (2) adds private sector credit. Column (3) adds an indicator for capital controls. Column (4) adds the Herfindahl-Hirschman Index of the banking sector. Granular Residual(-1) and Granular Residual(-2) indicate the inclusion of the respective lags of the Banking Granular Residual. All regressions include a set of time dummies. ***, ${ }^{* *}$, and ${ }^{*}$ denote significance at the $1 \%^{-}, 5 \%$, and $10 \%$-level, respectively.

\begin{tabular}{lllll}
\hline \hline & $(1)$ & $(2)$ & $(3)$ & $(4)$ \\
\hline Granular Residual & $0.0446^{* * *}$ & $0.0478^{* * *}$ & $0.0368^{*}$ & $0.0444^{* * *}$ \\
& $(0.0141)$ & $(0.0156)$ & $(0.0206)$ & $(0.0139)$ \\
Granular Residual(-1) & $0.0273^{*}$ & 0.0156 & 0.0197 & $0.0284^{*}$ \\
& $(0.0152)$ & $(0.0132)$ & $(0.0188)$ & $(0.0147)$ \\
Granular Residual(-2) & $0.0244^{* *}$ & 0.0183 & 0.0120 & $0.0247^{* *}$ \\
& $(0.0109)$ & $(0.0115)$ & $(0.0166)$ & $(0.0109)$ \\
Private Sector Credit & & -0.0126 & & \\
Capital controls & & $(0.0381)$ & & \\
& & & -0.0121 & \\
Herfindahl & & & & -0.0464 \\
& & & & $(0.0126)$ \\
\hline Long-Run Effect & $0.0963^{* * *}$ & $0.0817^{* * *}$ & $0.0685^{* *}$ & $0.0974^{* * *}$ \\
& $(0.0209)$ & $(0.0218)$ & $(0.0264)$ & $(0.0202)$ \\
\hline Observations & 253 & 232 & 158 & 253 \\
Number of countries & 35 & 32 & 26 & 35 \\
R-Squared & 0.273 & 0.261 & 0.299 & 0.285 \\
\hline \hline
\end{tabular}

